\title{
Role of Glutamatergic Projections from Ventral Tegmental Area to Lateral Habenula in Aversive Conditioning
}

\author{
(D)David H. Root, Carlos A. Mejias-Aponte, Jia Qi, and Marisela Morales \\ Neuronal Networks Section, Integrative Neuroscience Research Branch, National Institute on Drug Abuse, Baltimore, Maryland 21224
}

\begin{abstract}
The ventral tegmental area (VTA) plays roles in both reward and aversion. The participation of VTA in diverse behaviors likely reflects its heterogeneous neuronal phenotypes and circuits. Recent findings indicate that VTA GABAergic neurons that coexpress tyrosine hydroxylase $(\mathrm{TH})$ projecting to lateral habenula $(\mathrm{LHb})$ play a role in reward. In addition to these mesohabenular TH-GABAergic neurons, the VTA has many neurons expressing vesicular glutamate transporter 2 (VGluT2) that also project to LHb. To determine the behavioral role of mesohabenular VGluT2 neurons, we targeted channelrhodopsin2 to VTA VGluT2 neurons of VGluT2::Cre mice. These mice were tested in an apparatus where moving into one chamber stimulated VTA VGluT2 projections within the LHb, and exiting the chamber inactivated the stimulation. We found that mice spent significantly less time in the chamber where VGluT2 mesohabenular fiber stimulation occurred. Mice that received injections of mixed AMPA and NMDA glutamate receptor antagonists in LHb were unresponsive to VGluT2mesohabenular fiber stimulation, demonstrating the participation of LHb glutamate receptors in mesohabenular stimulation-elicited aversion. In the absence of light stimulation, mice showed a conditioned place aversion to the chamber that was previously associated with VGluT2-mesohabenular fiber stimulation. We conclude that there is a glutamatergic signal from VTA VGluT2-mesohabenular neurons that plays a role in aversion by activating LHb glutamatergic receptors.
\end{abstract}

Key words: addiction; aversion; dopamine; reward; VGluT2

\section{Introduction}

The ventral tegmental area (VTA) plays important roles in learning, motivation, reward, and aversion (Wise and Rompre, 1989; Deutch and Roth, 1990; Bromberg-Martin et al., 2010). The diverse behavioral roles of VTA may reflect differences in neuronal phenotypes and specific projection targets characteristic of this region. For instance, whereas extracellular dopamine concentrations are increased in nucleus accumbens following rewarding stimuli (Wise and Rompre, 1989; Roitman et al., 2008), extracellular dopamine concentrations are increased in prefrontal cortex following aversive stimuli (Thierry et al., 1976; Deutch and Roth, 1990). Further, whereas activation of VTA GABA neurons is aversive (Tan et al., 2012), activation of projections from a select group of VTA dopaminergic-GABAergic neurons to lateral habenula (LHb) is rewarding (Stamatakis et al., 2013).

In addition to dopaminergic and GABAergic neurons, the VTA contains neurons that express vesicular glutamate transporter 2 (VGluT2) mRNA (Yamaguchi et al., 2007). Emerging

\footnotetext{
Received May 19, 2014; revised Aug. 29, 2014; accepted Sept. 4, 2014.

Author contributions: D.H.R., C.A.M.-A., J.Q., and M.M. designed research; D.H.R., C.A.M.-A., and J.Q. performed research; D.H.R., C.A.M.-A., and J.Q. analyzed data; D.H.R., C.A.M.-A., and M.M. wrote the paper.

This work was supported by the Intramural Research Program of the National Institute on Drug Abuse. We thank Kyle E. Ireton for technical assistance.

The authors declare no competing financial interests.

This article is freely available online through the J Neurosci Author Open Choice option.

Correspondence should be addressed to Marisela Morales, PhD, Neuronal Networks Section, Integrative Neuro-

science Research Branch, National Institute on Drug Abuse, 251 Bayview Blvd., Suite 200, Baltimore, MD 21224.

E-mail:mmorales@intra.nida.nih.gov.

DOI:10.1523/JNEUROSCI.2029-14.2014

Copyright $\odot 2014$ the authors $\quad 0270-6474 / 14 / 3313906-05 \$ 15.00 / 0$
}

evidence indicates that the VTA VGluT2 neurons have a heterogeneous composition (Yamaguchi et al., 2011; Li et al., 2013; Morales and Root, 2014). Thus VTA VGluT2 neurons, like VTA dopamine and GABA neurons, may participate in different behaviors, depending on their phenotype and target sites. Regarding VGluT2 projection sites, recent findings from viral tracing studies indicate that VTA VGluT2 neurons innervate the LHb (Hnasko et al., 2012; Taylor et al., 2014). Here, we applied an optogenetic approach to determine whether VGluT2-mesohabenular neurons play a role in reward or aversion, and found that activation of fibers in LHb from VTA VGluT2 neurons elicits aversion. These results demonstrate for the first time a behavioral role of activating VTA VGluT2 neurons, and their participation in a mesohabenular pathway that regulates aversive conditioning.

\section{Materials and Methods}

All animal procedures were performed in accordance with National Institutes of Health Guidelines, and approved by the National Institute on Drug Abuse Animal Care and Use Committee.

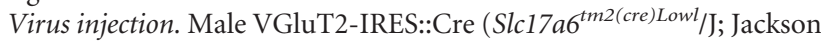
Laboratories) mice (20-30 g) were anesthetized with $1-5 \%$ isofluorane. AAV5-EF1 $\alpha$-DIO-hChR2(H134R)-eYFP, AAV5-EF1 $\alpha$-DIO-eYFP, or AAV5-EF1 $\alpha$-DIO-mCherry was injected in VTA [350 nl; flow rate, 100 $\mathrm{nl} / \mathrm{min} ;-3.2 \mathrm{~mm}$ anteroposterior (AP), $0.0 \mathrm{~mm}$ mediolateral (ML), $-4.3 \mathrm{~mm}$ dorsoventral (DV)]. Injections were made using the UltraMicroPump, Nanofil syringes, and 35 ga needles (WPI). Syringes were left in place for $10 \mathrm{~min}$ following injections to minimize diffusion. At least 8 weeks following virus injection, mice received intracranial ferrules or cannulas.

Drugs. The AMPA receptor antagonist CNQX (C239, $50 \mu \mathrm{M}$; SigmaAldrich) and the NMDA receptor antagonist AP-5 (A8054, $25 \mu \mathrm{M}$; 

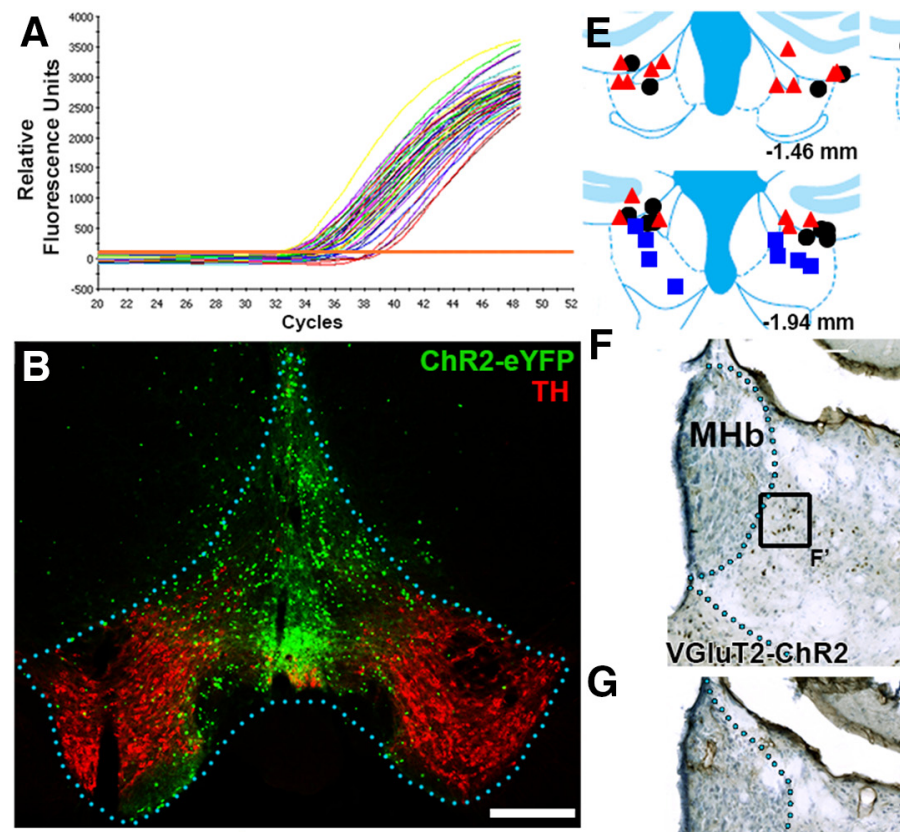

G
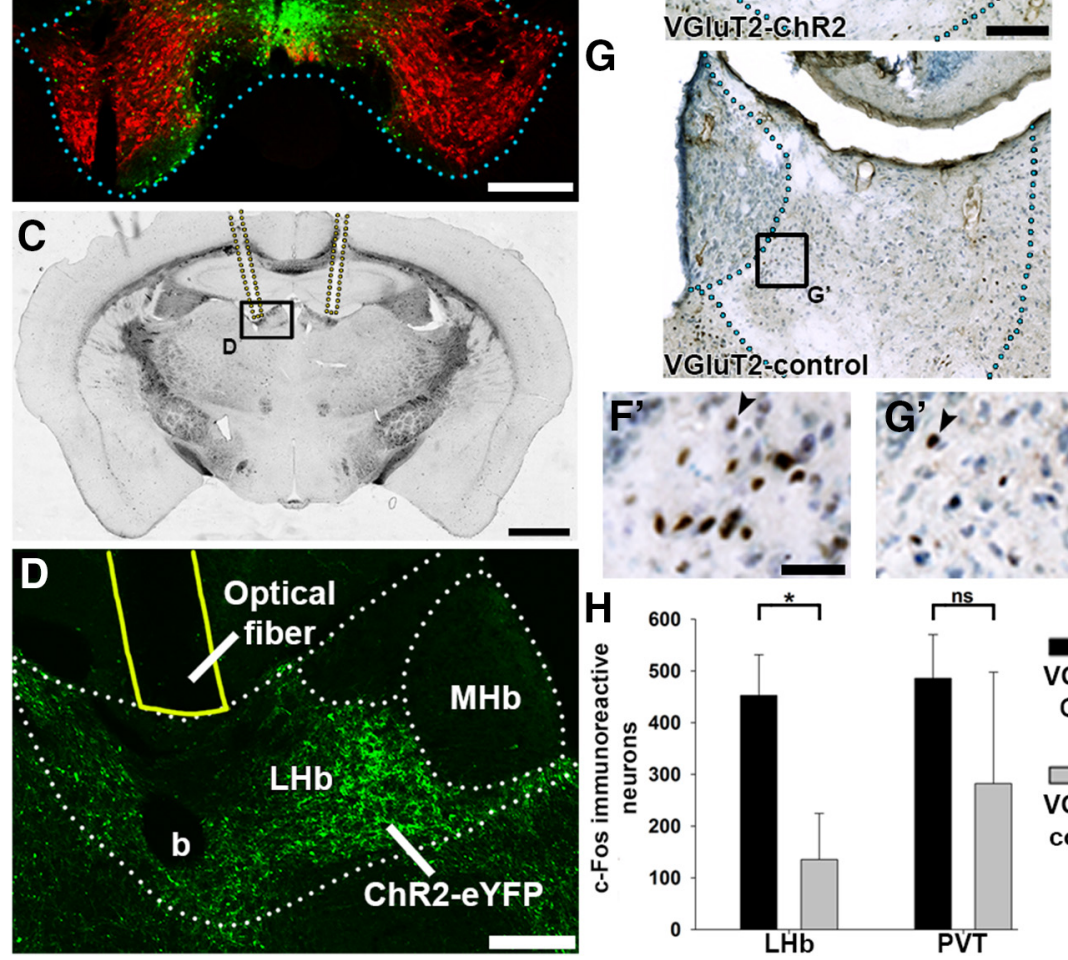

Figure 1. Location of viral injection site and optical probes. $A, q R T-P C R$ amplification curves showing detection of VGluT2 mRNA from individual VTA microdissected neurons expressing mCherry under the regulation of the VGluT2 promoter (65 neurons). $\boldsymbol{B}$, Expression of ChR2-eYFP at the viral injection site (VTA). VGluT2-eYFP neurons are localized to midline VTA (green), whereas TH-immunoreactive neurons are localized laterally (red). C, D, Example of an optical fiber placement in a ChR2-eYFP mouse. Yellow line indicates the optical fiber. eYFP fluorescence indicates axons from VTA VGluT2 neurons. b, Blood vessel. $\boldsymbol{E}$, Distribution of implanted fibers. $\boldsymbol{F}, \boldsymbol{G}$, Example LHb c-Fos immunoreactivity (brown/black puncta; $\boldsymbol{F}^{\prime}, \boldsymbol{G}^{\prime}$, arrowhead) in ChR2-eYFP $(\boldsymbol{F})$ and control (G) mice. $\boldsymbol{H}$, Light stimulation of VGluT2-mesohabenular fibers significantly increased c-Fos immunoreactivity in LHb but not paraventricular thalamus (PVT), in VGluT2-ChR2 mice compared with VGluT2-control mice [data are mean \pm SEM (error bars)]. ${ }^{*} p<0.05$. Scale bars: $\boldsymbol{B}, \boldsymbol{F}, \boldsymbol{G}, 0.25 \mathrm{~mm} ; \boldsymbol{C}, 1 \mathrm{~mm} ; \boldsymbol{D}, 0.2 \mathrm{~mm} ; \boldsymbol{F}^{\prime}, \boldsymbol{G}^{\prime}, 0.025 \mathrm{~mm}$.

Sigma-Aldrich) were mixed together in artificial CSF (aCSF; $124 \mathrm{~mm}$ $\mathrm{NaCl}, 5 \mathrm{~mm} \mathrm{KCl}, 1.25 \mathrm{~mm} \mathrm{NaH}_{2} \mathrm{PO}_{4}, 2 \mathrm{~mm} \mathrm{MgSO}_{4}, 10 \mathrm{~mm}$ glucose, $\mathrm{pH}$ 7.4). The CNQX-AP5 mixture dose was $\sim 70 \%$ lower than doses used in similar behavioral experiments (Mahler et al., 2013).

Apparatus. For place conditioning we used a conditioned place preference apparatus (AnyBox, Stoelting) consisting of two large outer chambers $(20 \times 18 \times 35 \mathrm{~cm})$ with distinct wall drawings, connecting by a small chamber $(20 \times 10 \times 35 \mathrm{~cm})$. Mouse position was monitored via an overhead closed-circuit camera interfaced with video tracking software (AnyMaze, Stoelting).

Laser microdissection and real-time quantitative PCR. Mice $(n=3)$ that received intra-VTA injections of AAV5-EF1 $\alpha$-DIO-mCherry were anes-
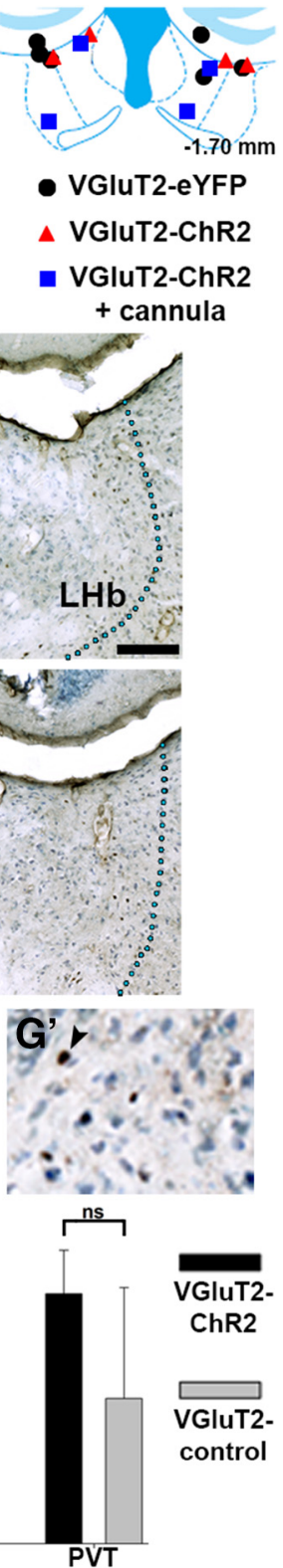

thetized with chloral hydrate $(400 \mathrm{mg} / \mathrm{kg}$ ) and perfused transcardially with $10 \%$ RNAlater (Ambion) in $0.1 \mathrm{M}$ phosphate buffer (PB), pH 7.4 (Li et al., 2013). Brains were frozen and midbrain sections $(10 \mu \mathrm{m})$ were collected onto polyethylenenaphthalene-coated slides (Leica). Sections were fixed with ice-cold acetone for $2 \mathrm{~min}$, rinsed in $\mathrm{PB}$, and incubated for 6 min with mouse anti-mCherry antibody (1:40 dilution; Clontech). Samples were rinsed in $\mathrm{PB}$ and incubated for 4 min with Alexa Fluor 594-conjugated goat anti-mouse antibody (1:25 dilution; Invitrogen). Antibody solutions were supplemented with $0.1 \%$ Triton X-100 and $400 \mathrm{U} / \mathrm{ml}$ RNase inhibitor (Promega). Sections were rinsed in $\mathrm{PB}$ and dehydrated in ethanol. Individual mCherry-expressing VTA neurons were microdissected (bregma -3.16 to $-3.64 \mathrm{~mm}$ ) under $40 \times$ objective lens and collected into $0.5 \mathrm{ml} \mathrm{PCR}$-tube caps containing $20 \mu \mathrm{l}$ of RNA extraction buffer. RNA was extracted using a PicoPure RNA Isolation Kit (Molecular Devices). Genomic DNA was removed by DNase digestion using the DNA-free kit (Qiagen). Extracted RNA was transcribed to cDNA with SuperScript III First-Strand Synthesis Super Mix (Invitrogen). $\beta$-Actin (4352933, Applied Biosystems) was amplified, and detection of $\beta$-actin mRNA was used to confirm the presence of intact mRNA for each sample. VGluT2 primers were obtained from Applied Biosystems (Mm00499876_m1). The quantitative PCR (qPCR) was performed with the iCycler iQ Real Time PCR Detection System (Bio-Rad Laboratories) with the following conditions: $50^{\circ} \mathrm{C}$ for $2 \mathrm{~min}, 95^{\circ} \mathrm{C}$ for $10 \mathrm{~min}, 45$ cycles at $95^{\circ} \mathrm{C}$ for $15 \mathrm{~s}$ and at $60^{\circ} \mathrm{C}$ for $60 \mathrm{~s}$. An external standard curve was used based on a mouse VGluT2-plasmid cDNA and qPCR results were analyzed using the iCycler iQ Real Time PCR Detection System Software.

Real-time place conditioning. Mice $(n=19)$ were implanted with bilateral $200 \mu \mathrm{m}$ core optical fibers (BFL37-200, ThorLabs) epoxied inside optical ferrule sticks (MM-FER2007C2300, Precision Fiber Products) dorsal to LHb $\left(-1.7 \mathrm{AP}, \pm 1.0 \mathrm{ML}\right.$ at $\left.9^{\circ},-2.7 \mathrm{DV}\right)$. After 1 week of recovery, mice were connected to bilateral optical fibers (CPL128513-50-6-9-1501000-2-8, Precision Fiber Products), placed inside the connecting chamber, and allowed to explore the entire apparatus on each session. Mice were habituated to the apparatus for 15 min without light delivery. The next day, mice were placed in the apparatus without light delivery (No Light session). Mice were tested in two stages. During Stage 1 initial-pairing sessions (30 min sessions for 4 consecutive days), each time that the mice entered chamber A (light-paired chamber), light was delivered (473 nm, $10 \mathrm{~ms}$ duration, $50 \mathrm{~ms}$ period, $2.04-4.62 \mathrm{~mW} /$ $\mathrm{mm}^{2}$ from the fiber tip; Deisseroth, 2012) until mice exited this chamber. Entry and exit of chamber B (light-unpaired chamber) did not result in light delivery. To determine conditioned preference or aversion, the day after the fourth initial-pairing session, mice were allowed to explore the apparatus without light delivery for a 15 min test session (Test 1). The next day after the Test 1 session, mice were tested in Stage 2 in which light delivery was switched to chamber B (reversal-pairings), and mice were trained during consecutive days under conditions in which each time that mice entered chamber B (light-paired chamber), light was delivered 
until mice exited this chamber. During Stage 2, entry and exit of chamber A (light-unpaired chamber) did not result in light delivery. The day after the fourth reversal-pairing session, mice were allowed to explore the apparatus without light delivery for $15 \mathrm{~min}$ to test for the second time (Test 2) conditioned preference or aversion.

Optical stimulation and intra-LHb injections. Mice $(n=6)$ were implanted with bilateral guide cannulas (C316G-24 ga, Plastics One) dorsal to $\mathrm{LHb}(-1.7 \mathrm{~mm} \mathrm{AP,} \pm 1.0 \mathrm{~mm} \mathrm{ML}$ at $\left.9^{\circ},-1.2 \mathrm{~mm} \mathrm{DV}\right)$. One week after recovery, mice were placed inside the connecting chamber, allowing exploration of the entire apparatus on each session (see Real-time place conditioning). To test for participation of $\mathrm{LHb}$ glutamate receptors on the effects by lightactivation of ChR2-mesohabenular fibers, bilateral needles (C316I-31 ga, Plastics One) were inserted $2 \mathrm{~mm}$ ventral to the tip of the guide cannulas, and microinjections $(300 \mathrm{nl}$, $100 \mathrm{nl} / \mathrm{min}$ ) of CNQX/AP-5 were delivered bilaterally into $\mathrm{LHb}$. Three minutes following injections, needles were removed and $64 \mu \mathrm{m}$ core optical fibers were bilaterally inserted $1.5 \mathrm{~mm}$ ventral to the guide cannula tip before mice were placed inside the apparatus for $30 \mathrm{~min}$. When mice entered the light-paired chamber, light was delivered ( $473 \mathrm{~nm}, 10 \mathrm{~ms}$ duration, 50 $\mathrm{ms}$ period, $2.04-4.62 \mathrm{~mW} / \mathrm{mm}^{2}$ ) until mice exited this chamber. Entrance into the lightunpaired chamber did not result in light delivery. One to $10 \mathrm{~d}$ after intra-LHb injections of glutamate receptor antagonists, mice received a bilateral intra-LHb injection of aCSF $(300 \mathrm{nl}$, $100 \mathrm{nl} / \mathrm{min}$ ) before being placed within the apparatus for $30 \mathrm{~min}$. Light-delivery contingen-

cies were the same as in the CNQX/AP-5 test. Pilot experiments injecting vehicle with ink estimated the spread of injection to cover an area of $0.055 \pm 0.004 \mathrm{~mm}^{2}$ of LHb spanning $0.6 \mathrm{~mm}$ rostral-caudal.

c-Fos-immunodetection. Eight mice implanted with LHb bilateral optical fibers were habituated to the conditioned place preference apparatus for $2 \mathrm{~h}$ without light delivery on 3 consecutive days. Five of these mice expressed ChR2 in VTA (VGluT2-ChR2). Three (VGluT2-control) did not. Following habituation, mice were placed in the apparatus and light was delivered ( $473 \mathrm{~nm}, 10 \mathrm{~ms}$ duration, $50 \mathrm{~ms}$ period, $2.04-4.62 \mathrm{~mW}$ / $\mathrm{mm}^{2}$ ) in $5 \mathrm{~s}$ trains every $15 \mathrm{~s}$ over the course of $15 \mathrm{~min}$. Two hours following the onset of light delivery, mice were anesthetized with isofluorane and perfused transcardially with $4 \%(\mathrm{w} / \mathrm{v})$ paraformaldehyde in 0.1 м PB, pH 7.3. LHb sections $(30 \mu \mathrm{m})$ were prepared and placed in blocking solution ( $4 \%$ bovine serum albumin in $\mathrm{PB}$ supplemented with $0.3 \%$ Triton X-100) for $1 \mathrm{~h}$ before incubating with rabbit anti-c-Fos (sc52, Santa Cruz Biotechnology) in blocking solution overnight at $4^{\circ} \mathrm{C}$. The sections were washed in $\mathrm{PB}$, incubated with biotinylated goat anti-rabbit antibody (1:200; Vector) for $1 \mathrm{~h}$, washed in $\mathrm{PB}$, and incubated with avidin-biotinylated horseradish peroxidase (1:200; Vector). Sections were rinsed; the peroxidase reaction was developed with $0.05 \% 3$, 3-diaminobenzidine- $4 \mathrm{HCl}$ and $0.003 \% \mathrm{H}_{2} \mathrm{O}_{2}$; and sections were counterstained with toluidine blue. c-Fos-immunoreactive neurons were counted in Photoshop (Adobe).

Statistics. Tests were conducted in SPSS (IBM). For real-time place conditioning, an omnibus 3 (chamber) $\times 11$ (session) $\times 2$ (group) multivariate ANOVA tested the change in percentage of time spent within each chamber over the course of the entire experiment. The number of seconds spent within each chamber was divided by the duration of each session. If the assumption of sphericity was not met (Mauchley's test), the Greenhouse-Geisser correction was used. If a significant chamber-sessiongroup interaction was yielded from the ANOVA, Sidak-adjusted pairwise
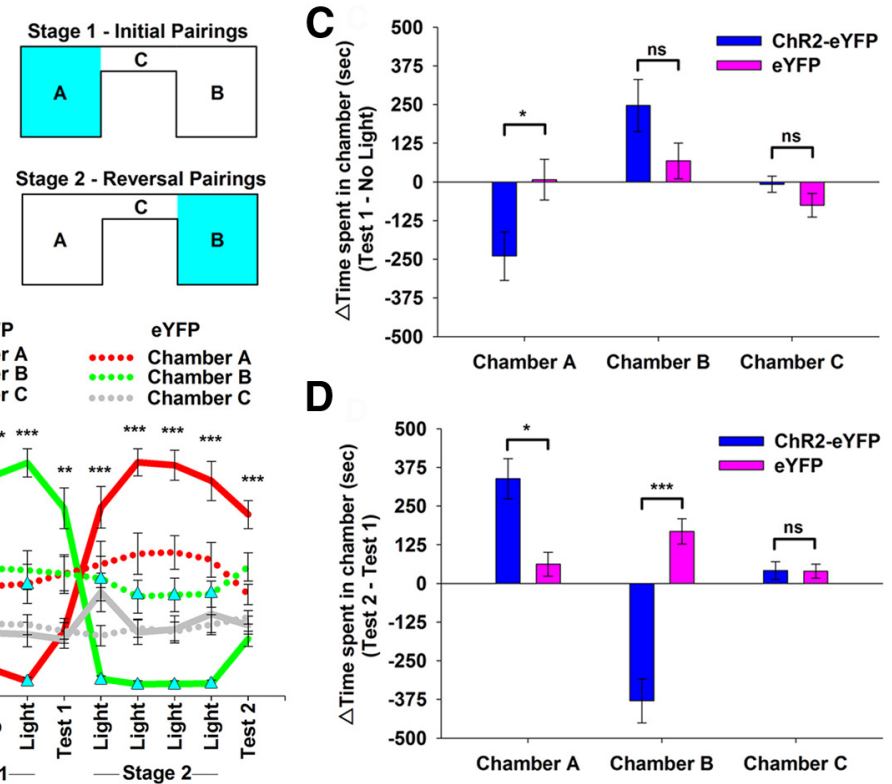

eYFP

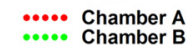

Chamber B

*********

D

Figure 2. Activation of VGluT2-mesohabenular fibers elicits aversion and forms a conditioned place aversion. $\boldsymbol{A}$, VGluT2::Cre mice were 作 (blue shad(dotted lines). ChR2-eYFP mice spent significantly less time in the chamber where light activation of mesohabenular (he ChR2-eYFP mice selectively spent less time in the mesohabenular lightactivated chamber B. Chamber-group interaction, $F_{(2,34)}=26.47, p<0.001$. Data are mean \pm SEM (error bars). Sidak-adjusted pairwise comparisons: ${ }^{*} p<0.05,{ }^{* *} p<0.01,{ }^{* * *} p<0.001$.

comparisons were used to examine whether within ChR2-eYFP mice or within eYFP mice a significant difference in percentage of time spent between chambers A and B occurred. To evaluate whether mice formed a conditioned place preference or aversion, an omnibus 3 (chamber) $\times 2$ (group) multivariate ANOVA examined the difference in seconds between subsequent tests for each chamber. If a significant chamber-group interaction was yielded from the ANOVA, Sidak-adjusted pairwise comparisons were used to examine differences between ChR2-eYFP and eYFP mouse groups.

For intra-LHb injection and optical stimulation experiments, an omnibus 3 (chamber) $\times 3$ (session) repeated-measures ANOVA examined the percentage of time spent within each chamber over sessions. If a significant chamber-session interaction was yielded from the ANOVA, Sidak-adjusted planned pairwise comparisons were used to examine differences between chambers during the No Light session and the intra- $\mathrm{LHb}$ glutamate receptor antagonist session or during the intra-LHb glutamate receptor antagonist session and the intra-LHb aCSF session. To examine locomotor differences induced by intra-LHb glutamate receptor antagonists and aCSF, average speed of locomotion during each session was calculated by AnyMaze software and compared using a paired $t$ test.

\section{Results}

To determine the selective expression of Cre-recombinase within VTA VGluT2 neurons in VGluT2::Cre mice, VGluT2 mRNA expression was examined in VTA neurons expressing mCherry under the regulation of the VGluT2 promoter. By qRT-PCR, we detected VGluT2 mRNA in each VTA laser-microdissected mCherry-expressing neuron (65 mCherry neurons; Fig. 1A). We next examined the neuronal effects of light-activating the VTA VGluT2 projection to LHb by measuring the expression of c-Fos 
immunoreactivity in LHb neurons as well in neurons immediately ventral of the $\mathrm{LHb}$ in the paraventricular thalamus. Light stimulation of mesohabenular VGluT2 inputs to LHb induced significantly greater expression of c-Fos immunoreactivity in LHb neurons of VGluT2-ChR2 mice compared with VGluT2control mice $\left(t_{(6)}=2.53, p<0.05\right.$; Fig. $\left.1 F-H\right)$. c-Fos immunoreactivity was also observed in the paraventricular thalamus, near the fasciculus retroflexus, but did not significantly differ between groups, $t_{(6)}=1.05, p>0.05$.

To determine whether LHb light stimulation of VTA VGluT2 inputs results in conditioned place preference or aversion, we selectively activated this pathway in behaving mice after expressing ChR2-eYFP in VTA VGluT2 neurons (ChR2-eYFP mice) and compared with mice expressing eYFP without ChR2 in VTA VGluT2 neurons (eYFP mice; Fig. 1). To light-stimulate VGluT2mesohabenular fibers, both groups of mice were implanted with optical fibers dorsal to LHb. We placed the mice inside a threechamber apparatus consisting of two large chambers and a small connecting chamber (Fig. 2A). Mice first explored the maze in the absence of light stimulation (No Light session). After this exploration, mice were examined in a two-stage experimental protocol.

\section{Stage 1}

During the first session with no light delivery, and before Stage 1, there was no significant difference in time that mice spent between chambers $\mathrm{A}$ and $\mathrm{B}(p>0.05)$. In four subsequent daily sessions, entrance into a randomly assigned chamber A resulted in light stimulation of VGluT2-mesohabenular fibers. Light stimulation was terminated when mice exited this chamber and light was not delivered in any other chamber. During Stage 1 initialpairing sessions, ChR2-eYFP mice spent significantly less time in chamber A when compared with chamber B ( $p<0.001$; Fig. $2 B)$. The control eYFP mice spent significantly more time in chamber A when compared with chamber B on the first session of Stage 1 $(p<0.05)$, but did not show this significant difference in any other session. After initial-pairing sessions, mice were tested in the absence of light to evaluate conditioning. In this first testing session (Test 1), the ChR2-eYFP mice spent significantly less time than eYFP mice in chamber A $(p<0.05)$, demonstrating the formation of a conditioned place aversion to the place previously associated with light activation of VGluT2-mesohabenular fibers (Fig. 2C).

\section{Stage 2}

After completion of the Stage 1 portion of the experiment, lightdelivery contingencies were reversed such that light was delivered when mice entered chamber B and light was no longer delivered when mice entered chamber A. During four subsequent daily reversal-pairing sessions, ChR2-eYFP mice spent significantly less time in chamber B than in chamber A $(p<0.001)$. These findings indicate that the conditioned aversion to the initially paired chamber A was reversed following light activation of mesohabenular fibers in chamber B (Fig. 2B). No significant difference in time spent between chambers $A$ and $B$ was found for eYFP mice $(p>0.05)$. On each day that mice received light stimulation, the ChR2-eYFP mice exited the light-stimulation chamber at a significantly shorter latency than the eYFP mice $\left(F_{(1,17)}=99.65, p<\right.$ 0.001 ; mean \pm SEM on the last day that mice received light stimulation: $1.5 \pm 0.5 \mathrm{~s}$ in ChR2-eYFP mice vs $12.3 \pm 2.1 \mathrm{~s}$ in eYFP mice). After reversal-pairing sessions, mice were tested in the absence of light (Test 2). Relative to eYFP mice, ChR2-eYFP mice spent significantly less time in chamber B $(p<0.001)$, spent significantly more time in chamber $\mathrm{A}(p<0.01)$, and no difference was observed for chamber $\mathrm{C}(p>0.05$; Fig. $2 D)$, demonstrating the reversal of con-
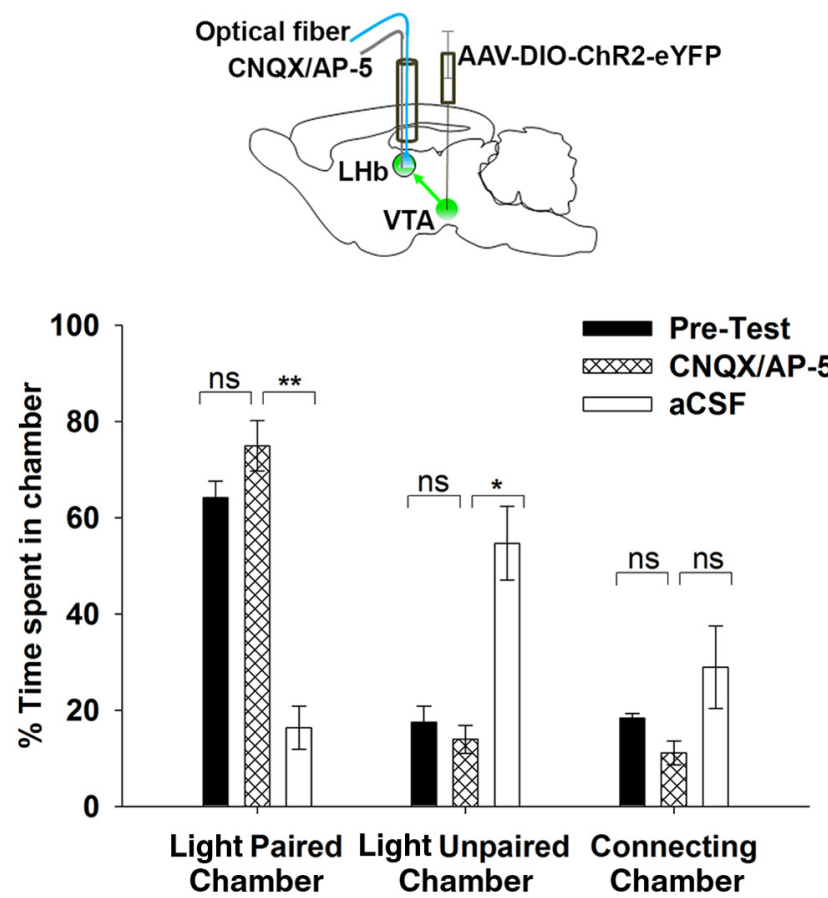

Figure 3. Aversion elicited by activation of VGluT2-mesohabenular fibers depends on $\mathrm{LHb}$ glutamate receptors. Top, VGluT2::Cre mice were injected with AAV Cre-dependent ChR2-eYFP vectors and cannulas were implanted dorsal to $\mathrm{LHb}$. Intra-LHb mix of CNQX/AP-5 or aCSF injections were made $3 \mathrm{~min}$ before optical stimulation. Bottom, Percentage of time spent in each chamber over the three tests. Intra-LHb CNQX/AP-5, but not intra-LHb aCSF, blocked mesohabenular light stimulation-elicited aversion. Session-chamber interaction, $F_{(4,20)}=18.24, p<0.001$. Data are mean \pm SEM (error bars). Sidak-adjusted pairwise comparisons: ${ }^{*} p \leq 0.05,{ }^{* *} p<0.01$.

ditioned place aversion. These results indicate that light stimulation of LHb projections from VTA VGluT2 neurons is aversive and capable of producing a conditioned aversion to places where light stimulation of mesohabenular fibers occurred.

\section{Effect of blocking LHb glutamate receptors on} mesohabenular-elicited aversion

To determine whether glutamate release from VTA VGluT2 fibers was responsible for the mesohabenular fiber stimulationelicited aversion, we tested a group of ChR2-eYFP mice in the following manner. Mice were allowed to explore the threechamber apparatus without light delivery. The chamber where mice spent more time during this Pre-Test session was selected as the light-paired chamber for subsequent sessions. Because ChR2eYFP mice immediately exit the place where light activation of VGluT2-mesohabenular fibers occurs, we hypothesized that injection of glutamate receptor antagonists into $\mathrm{LHb}$ before being placed within the apparatus would block the immediate exit behavior upon their entrance into the light-paired chamber. As hypothesized, there was no significant difference in time spent in the light-paired chamber during the no-light session when compared with the session in which glutamate receptor antagonists were injected and light was delivered to mesohabenular fibers (Fig. 3). To allow for the clearance of the glutamate receptor antagonists, the same mice were injected with aCSF in LHb $\geq 24$ $\mathrm{h}$ after injection of the antagonists, and tested for light-elicited exit behavior. In this test session, mice spent significantly less time in the light-paired chamber $(p<0.01)$, and significantly more time in the light-unpaired chamber $(p=0.05)$, with no change in the connecting chamber $(p>0.05$; Fig. 3$)$. Therefore, aversion elicited by light activation of ChR2 mesohabenular fi- 
bers from VTA VGluT2 neurons is dependent on the activation of LHb glutamate receptors. There was no significant difference in average velocity of mice when comparing after intra-LHb glutamate receptor antagonists and after intra-LHb aCSF $\left(t_{(5)}=\right.$ $-1.33, p>0.05)$, suggesting that locomotor capabilities of ChR2-eYFP mice were not altered by LHb glutamate receptor antagonists. We conclude that VTA participates in aversion via glutamate release from its terminals into the LHb.

\section{Discussion}

The VTA contains three major types of neurons: dopaminergic, GABAergic, and glutamatergic. While several studies have shown the participation of VTA dopaminergic and GABAergic neurons in both reward and aversion (Cohen et al., 2012; Lammel et al., 2012; Tan et al., 2012; Stamatakis et al., 2013), the behavioral roles of VTA VGluT2 neurons are unknown. Using place conditioning, we determined the rewarding or aversive effects elicited by activation of the pathway from VTA VGluT2 neurons to LHb, a structure known to play a role in conditioned aversion (Lammel et al., 2012; Stamatakis and Stuber, 2012) and reward (Stamatakis et al., 2013; Stopper and Floresco, 2014). We present evidence indicating that VTA VGluT2 neurons provide a glutamatergic input to $\mathrm{LHb}$, which when activated elicits aversion and promotes aversive conditioning.

Mesocortical and mesoaccumbal pathways have been suggested to play roles in the processing of aversive stimuli (Thierry et al., 1976; Deutch and Roth, 1990; Friedman et al., 2014). Our findings indicate that, in addition to these pathways, VTA VGluT2 neurons play a role in aversion by a mechanism in which VTA VGluT2 neurons release glutamate in LHb, resulting in activation of local glutamate receptors. As VTA VGluT2 neurons are major participants in mesocortical and mesoaccumbal pathways (Yamaguchi et al., 2011; Hnasko et al., 2012; Taylor et al., 2014), VTA VGluT2 neurons might participate in several aversion-related circuits. While some VTA VGluT2tyrosine hydroxylase $(\mathrm{TH})$ neurons project to $\mathrm{LHb}$ (Taylor et al., 2014), LHb dopamine release is not detected following LHb stimulation of VTA TH fibers (Stamatakis et al., 2013). Therefore we infer that $\mathrm{LHb}$ dopamine release does not play a role in the light-induced aversion or light-induced $\mathrm{LHb}$ c-Fos expression following $\mathrm{LHb}$ stimulation of VTA VGluT2 fibers.

$\mathrm{LHb}$ neurons are excited following cues that predict the absence of reward or cues predicting punishment (Matsumoto and Hikosaka, 2007, 2009). Therefore, it is possible that as a result of the activation of VGluT2-mesohabenular fibers, the mouse may associate negative motivation with the environment in which mesohabenular stimulation occurred, leading to the avoidance of this environment. In addition to VTA inputs to LHb, excitatory inputs to LHb from the entopeduncular nucleus are sufficient to evoke aversive conditioning (Shabel et al., 2012), but it remains to be determined how these two excitatory pathways to the LHb contribute to other behaviors or clinical conditions.

The brain structures targeted by LHb neurons receiving inputs from VTA VGluT2 neurons mediating mesohabenularelicited aversion are at present unknown. Potential targeted structures include both the rostromedial tegmental nucleus and the dorsal raphe, as both brain structures receive glutamatergic inputs from the LHb, and both participate in habenula-elicited aversion (Jhou et al., 2009; Pobbe and Zangrossi, 2010; Stamatakis and Stuber, 2012). In conclusion, our findings indicate that a glutamatergic projection from VTA VGluT2 neurons to LHb elicits aversive conditioning. Further, these studies demonstrate for the first time a behavioral function of activating a VTA VGluT2 neuronal pathway.

\section{References}

Bromberg-Martin ES, Matsumoto M, Hikosaka O (2010) Dopamine in motivational control: rewarding, aversive, and alerting. Neuron 68:815-834. CrossRef Medline

Cohen JY, Haesler S, Vong L, Lowell BB, Uchida N (2012) Neuron-typespecific signals for reward and punishment in the ventral tegmental area. Nature 482:85-88. CrossRef Medline

Deisseroth K (2012) Predicted irradiance values: model based on direct measurements in mammalian brain tissue. Available at http://web. stanford.edu/group/dlab/cgi-bin/graph/chart.php.

Deutch AY, Roth RH (1990) The determinants of stress-induced activation of the prefrontal cortical dopamine system. Prog Brain Res 85:367-403. CrossRef Medline

Friedman AK, Walsh JJ, Juarez B, Ku SM, Chaudhury D, Wang J, Li X, Dietz DM, Pan N, Vialou VF, Neve RL, Yue Z, Han MH (2014) Enhancing depression mechanisms in midbrain dopamine neurons achieves homeostatic resilience. Science 344:313-319. CrossRef Medline

Hnasko TS, Hjelmstad GO, Fields HL, Edwards RH (2012) Ventral tegmental area glutamate neurons: electrophysiological properties and projections. J Neurosci 32:15076-15085. CrossRef Medline

Jhou TC, Fields HL, Baxter MG, Saper CB, Holland PC (2009) The rostromedial tegmental nucleus (RMTg), a GABAergic afferent to midbrain dopamine neurons, encodes aversive stimuli and inhibits motor responses. Neuron 61:786-800. CrossRef Medline

Lammel S, Lim BK, Ran C, Huang KW, Betley MJ, Tye KM, Deisseroth K, Malenka RC (2012) Input-specific control of reward and aversion in the ventral tegmental area. Nature 491:212-217. CrossRef Medline

LiX, Qi J, Yamaguchi T, Wang HL, Morales M (2013) Heterogeneous composition of dopamine neurons of the rat A10 region: molecular evidence for diverse signaling properties. Brain Struct Funct 218:1159-1176. CrossRef Medline

Mahler SV, Smith RJ, Aston-Jones G (2013) Interactions between VTA orexin and glutamate in cue-induced reinstatement of cocaine seeking in rats. Psychopharmacology 226:687-698. CrossRef Medline

Matsumoto M, Hikosaka O (2007) Lateral habenula as a source of negative reward signals in dopamine neurons. Nature 447:1111-1115. CrossRef Medline

Matsumoto M, Hikosaka O (2009) Representation of negative motivational value in the primate lateral habenula. Nat Neurosci 12:77-84. CrossRef Medline

Morales M, Root DH (2014) Glutamate neurons within the midbrain dopamine regions. Neuroscience 282C:60-68. CrossRef Medline

Pobbe RL, Zangrossi H Jr (2010) The lateral habenula regulates defensive behaviors through changes in 5-HT-mediated neurotransmission in the dorsal periaqueductal gray matter. Neurosci Lett 479:87-91. CrossRef Medline

Roitman MF, Wheeler RA, Wightman RM, Carelli RM (2008) Real-time chemical responses in the nucleus accumbens differentiate rewarding and aversive stimuli. Nat Neurosci 11:1376-1377. CrossRef Medline

Shabel SJ, Proulx CD, Trias A, Murphy RT, Malinow R (2012) Input to the lateral habenula from the basal ganglia is excitatory, aversive, and suppressed by serotonin. Neuron 74:475-481. CrossRef Medline

Stamatakis AM, Stuber GD (2012) Activation of lateral habenula inputs to the ventral midbrain promotes behavioral avoidance. Nat Neurosci 15: 1105-1107. CrossRef Medline

Stamatakis AM, Jennings JH, Ung RL, Blair GA, Weinberg RJ, Neve RL, Boyce F, Mattis J, Ramakrishnan C, Deisseroth K, Stuber GD (2013) A unique population of ventral tegmental area neurons inhibits the lateral habenula to promote reward. Neuron 80:1039-1053. CrossRef Medline

Stopper CM, Floresco SB (2014) What's better for me? Fundamental role for lateral habenula in promoting subjective decision biases. Nat Neurosci 17:33-35. CrossRef Medline

Tan KR, Yvon C, Turiault M, Mirzabekov JJ, Doehner J, Labouèbe G, Deisseroth K, Tye KM, Lüscher C (2012) GABA neurons of the VTA drive conditioned place aversion. Neuron 73:1173-1183. CrossRef Medline

Taylor SR, Badurek S, Dileone RJ, Nashmi R, Minichiello L, Picciotto MR (2014) GABAergic and glutamatergic efferents of the mouse ventral tegmental area. J Comp Neurol 522:3308-3334. CrossRef Medline

Thierry AM, Tassin JP, Blanc G, Glowinski J (1976) Selective activation of mesocortical DA system by stress. Nature 263:242-244. CrossRef Medline

Wise RA, Rompre PP (1989) Brain dopamine and reward. Annu Rev Psychol 40:191-225. CrossRef Medline

Yamaguchi T, Sheen W, Morales M (2007) Glutamatergic neurons are present in the rat ventral tegmental area. Eur J Neurosci 25:106-118. CrossRef Medline

Yamaguchi T, Wang HL, Li X, Ng TH, Morales M (2011) Mesocorticolimbic glutamatergic pathway. J Neurosci 31:8476-8490. CrossRef Medline 